\title{
PENENTUAN LOKASI USAHA BERDASARKAN ARAH MATA ANGIN (Studi fenomenologi Pada Pemborong padi Di Kecamatan Kesamben)
}

\author{
Endah Masrunik1 ${ }^{1}$ Arif Wahyudi², Redy Khoirianto ${ }^{3}$, Moh. Zaki kurniawan ${ }^{4}$ \\ 1,2,3Fakultas Ekonomi Universitas Islam Balitr, ${ }^{4}$ Fakultas Ekonomi Universitas Trunojoyo
}

email: 1endahmasrunik@gmail.com, 2rea.gumilang999@gmail.com, $\quad$ redykhoirianto@gmail.com. tzaki.kurniawan@trunojoyo.ac.id,

\section{Kata kunci:}

Penentuan Lokasi

Kepercayaan

Fenomenologi

\section{Keywords:}

location determination

Belife

phenomenology

Endah Massrunik, dkk. (2021).

Penentuan Lokasi Usaha

Berdasarkan Arah mata Angin (Stui

Fenomenologi Pada Pemborong Padi

Di Kecamatan kesamben).

Akuntabilitas: Jurnal Ilmiah Ilmu-

Ilmu Ekonomi, 14(1), 69-77

\begin{abstract}
ABSTRAK
Penelitian ini bertujuan untuk mengungkapkan strategi para pemborong padi dalam menetukan lokasi usaha yang tepat sesuai arah mata angin guna memenuhi kebutuhan konsumen. Pemilihan lokasi yang tepat akan berdampak pada berkembangnya usaha tersebut. Metode dalam penelitian ini menggunakan metode kualitatif dengan pendekatan fenomenologi, dimana peneliti menggali makna yang tinggi dan dalam dari kejadian-kejadian atau fenomena-fenomena yang diterapkan oleh para pemborong dalam memilih lokasi usaha. Hasil dari penilitian ini bahwa para pemborong memilih lokasi berdasarkan kepercayaan terhadap arah mata angin yang disesuaikan dengan hari pasaran jawa. Yang mana hal ini sulit untuk diterima secara nalar. Karena pemilihan lokasi usaha didasarkan pada keyakinan magis. Pemborong percaya pada arah mata angin yang disesuaikan dengan hari dan pasaran tertentu ada yang istimewa dan akan menghasilakan keuntungan apabila digunakan untuk kegiatan usaha.
\end{abstract}

\section{ABSTRACT}

This study aims to reveal the strategies of rice wholesalers in determining the right business location according to the cardinal directions to meet consumer needs. Choosing the right location will have an impact on the development of the business. The method uses qualitative method and phenomenological approach, where the researcher explores the high and deep meaning of events or phenomena applied by the contractors in choosing a business location. The result proves the contractors choose the location based on the belief in the wind direction which is adjusted to the Java market day which is difficult to accept logically. Furthermore the choice of business location is based on magical beliefs. The contractor believes that the wind direction that is adjusted to certain days and markets is special and will generate profits used for business activities.

\section{PENDAHULUAN}

Kepuasan konsumen menjadi prioritas utama dalam pandangan usahawan, sehingga memaksa para usawahan harus berfikir keras untuk melakukan inovasi 
dan strategi yang tepat dalam memenuhi kebutuhan konsumen. Adapun beberapa faktor yang harus diperhatikan oleh usahawan yaitu kualitas produk, ketersediaan produk, lokasi usaha dan beberapa faktor lainnya.

Strategi pemelihan lokasi juga terpengaruh dari kondisi lingkungan sekitar dan kepercayaan masyarakat dimana lokasi usaha tersebut berada. Banyak usahawan pemula yang memilih lokasi usaha dengan mempertimbangkan hal-hal yang berbau mistis yang dianggap irasional. Tradisi mendatangi orang-orang pintar (dukun) banyak dilakukan oleh usahawan pemula untuk melihat lokasi dan arah yang tepat dalam menjalankan usahanya.

Sejalan juga dengan yang disampaikan oleh (Musrifah et al., 2017)Yang menyatakan bahwa dalam memajukan usaha selain menggunakan teori-teori ekonomi yang sudah ada juga menggunakan irrasional believe. Irrasional believe disini diwujudkan dalam hal memilih lokasi dan arah usaha sesuai hari pasaran yang sesuai dengan perhitungan kepercayaan adat jawa.

Padahal dalam memilih lokasi usaha hal yang seharusnya menjadi pertimbangan adalah biaya operasional yang murah (Maulana, 2018), sehingga perusahaan dapat berjalan secara efektif dan efisien. Berdasarkan hal tersebut maka penelitian ini bertujuan meneliti fenomena dimasyarakat dimana ketika memilih suatu lokasi untuk dijadikan tempat usaha adalah berdasarkan arah mata angin yang kemudian di sesuaikan dengan perhitungan jawa dengan subjek penelitian adalah para pemborong padi di wilayah kecamatan kesamben. Berbeda dengan penelitian (Eka P et al., 2016) dimana penentuan lokasi usaha didasarkan dengan metode simple additive weighting yang dilakukan pada took fashion di Surakarta. Berbeda juga dengan penelitian Fitriyani et al., (2019) dimana penentuan lokasi usaha sangat dipengaruhi oleh lingkungan bisnis serta faktor biaya lokasi.

Faktor penentuan lokasi tidak hanya bersinggungan dengan letak sumber bahan baku, ketersediaan tenaga kerja, saluran distribusi dan lokasi pasar (solihin, 2014:209) Tetapi juga berkaitan dengan faktor lain yang menjadi pertimbangan para usahawan didaerah Kecamatan Kesamben yang dapat menjaga keberlangsungan hidup usahanya. Biaya dan lingkungan bisnis juga merupakan faktor yang menjadi pertimbangan dalam menjalankan usahanya. Selain itu faktor yang tidak kalah 
menarik faktor yang didasarkan budaya terhadap kepercayaan magis. Yang menyakini bahwa lokasi dan arah tertentu sesuai hari pasaran jawa akan membawa kesuksesan terhadap usahanya kelak.

Budaya merupakan suatu kebiasaan-kebiasaan atau kepercayaan yang dilakukan oleh sekelompook masyarakat didaerah tertentu sehingga ini menjadi dasar dimana usahawan berada maka akan mengikuti suatu kebudayaan didaerah tersebut. Sistem kepercayaan akan mempengaruhi pandangan hidup, kebiasaan cara berkomunikasi, cara berdagang dalam masyarakat (Maryaeni, 2005;23) Daerah yang kental akan suasana magis juga akan mempengaruhi keberlangsungan suatu usaha di daerah tersebut. Karena budaya merupakan perwujudaan kasih saying dari nenek moyang kepada generasi penerusnya.Sehingga generasi penurus tersugesti untuk melestarikan budaya tersebut.

Budaya mistik yang sampai saat ini masih sulit dipisahkan dari masyarakat pedesaan khususnya didaerah kabupaten blitar yaitu praktek perdukunan. Praktek dukun selain untuk pengobatan juga praktek dukun sebagai usaha untuk memajukan usahanya.Banyak yang membuat sesajen-sesajen untuk persembahan.Selain itu juga banyak yang mendatangi dukun untuk menentukan lokasi dan arah usahawan dalam menjalankan kegiatan usahanya.Selain itu apabila usaha sedang sepi juga banyak yang pergi ke dukun agar usahanya kembali ramai.

Senada juga dengan yang diungkapkan oleh (Musrifah et al., 2017) bahwa dipedesaan pengobatan dukun secara mistis lebih dipercaya dapat menyembuhkan penyakit daripada rumah sakit. Begitu juga dengan penetuan lokasi usaha. Setiap lokasi dan arah tertentu berdasarkan hari pasaran jawa diyakini memiliki keistimewaan sendiri-sendiri.Sehingga sangat penting untuk menjalankan usahanya memerlukan pertimbangan dalam menentukan lokasi dan arah usaha.

\section{METODE PENELITIAN}

Moleong, (2018) mendiskripsikan penelitian kualitatif yaitu penelitian yang berusaha menjelaskan fenomena, kejadian yang dialami oleh subjek penelitian. Sejalan dengan yang dikemukakan oleh (Sugiyono, 2016) penelitian yang belum memiliki kejelasan terhadap permaslahannya dikatakan penelitian kualitatif karena 
diperlukan penggalian yang lebih dalam pada fenomena yang terjadi pada objek penelitian.

Di dalam penelitian ini berusaha mengkaji suatu peristiwa kehidupan nyata yang dialami subjek penelitian dalam hal ini adalah para pemborng padi diwilayah Kecamatan Kesamben.Serta mendiskripsikan bagaimana para pemborong menentukan lokasi yang tepat dalam menjalankan usahanya.

\section{PEMBAHASAN}

Kecamatan Kesamben merupakan bagian dari Kabupaten Blitar bagian timur. Kecamatan Kesamben memiliki wiayah yang sebagian besar berupa persawahan. Dengan luasnya lahan sawah yang ada di daerah kesamben memunculkan banyak para penebas (pemborong) padi yang keliling ke sawah-sawah tersebut.

Dalam menentukan atau mencari dagangannya para penebas akan keliling ke desa-desa yang terdapat sawah. Namun dalam menetukan lokasi berkeliling selain melihat daerah sawah yang padinya sudah mulai menguning, pemborong juga memperhitungkan arah dalam bepergian mencari dagangannya. Hal ini sesuai dengan yang diungkapkan oleh salah satu narasumber yang kami temui disawah, yang disajikan dalam kutipan wawancara berikut ini"

"lek mangkat golek dagangan yo kudu di itung disik, ora sokor mangkat. Wong golek rejeki ki yo kudu usaha lan pasrah. Salah sawijine usaha yo iki, kudu di etung. Marai wong jowo. Dadi le nyambut ki yo ben kasil: [kalau berangkat mencari barang dagangan dihitung dulu, tidak langsung berangkat. Karena mencari rezeki harus berusaha dan pasrah. Salah satunya ya usaha ini, harus di hitung. Karena orang jawa. Biar kalau bekerja bisa menghasilkan].

Hal senada juga diungkapkan oleh narasumber lainnya sebagai penebas padi. Yang disajikan sebagai berikut:

"maune aku ndak percaya mbi etungan jowo, tapi san di wei weruh koncoku. Lek rep mangkat ki kon ngetungi, awak edewe wong jowo yo kudu manut adat e wong jowo. Yo alkhamdulillah, asile kenek tak rasakne. Missal o rugi, rugi ne ndak sepiro". [sebelumnya saya tidak percaya dengan perhitungan jawa, tapi karena diberitahu teman saya. Kalau mau berangkat di suruh menghitung dulu, karena kita orang jawa harus menganut adatnya orang jawa. Ya bersyukur, hasilnya bisa dirasakan. Misalnya ada ruginya tidak seberapa]. 
Begitu juga diungkapkan oleh narasumber lainnya sebagai penebas padi. Yang disajikan sebagai berikut:

"dadi wong jowo ki kudu ngerti adate jowo, lek arep budal nyambut gawe kudu mritungno nyadi parane mengko lek budal nyambut gawe, liyane kwi kudu ngerti itungitunganane dino lan pasaran koyoto pon, wage, kliwon, legi, lan pahing. Seumpomo pas dino pasaran pon kudune lek budal golek dagangan mlaku nyang wetan dadi ben penak pamane awake dewe arep golek dagangan lan metong dagangan ben lancar".[kalau jadi orang jawa harusnya mengerti tentang adat jawa, jika kalau mau bekerja harus memperhitungkan kemana nantinya kalau berangkat kerja, selain itu harus tau perhitungan dan pasaran jawa seperti pon, wage, kliwon, legi, dan pahing. Seandainya pasaran pon harus berangkat ke arah timur sehingga biar mudah dalam mencari barang dagangan dan bertransaksi].

Selanjutnya juga diungkapkan oleh narasumber lainnya sebagai penebas padi. Yang disajikan sebagai berikut :

"rejeki wes onok seng ngator menungso mek iso berusaha supoyo rejeki kwi iso moro neng awake dewe, podo karo nentokne nyandi lek awake dewe golek dagangan, lek pasaran iki awake dewe kudu mlaku nyandi lan sak piturute, mergo nga enek salahe peroyo adat seng wes di waresne ambi leluhor mbiyen seng penting tetep ndongo lan usoho". [rezeki itu sudah yang mengatur manusia hanaya bisa berusaha supaya rezeki itu bisa datang ke kita, sama halnya menentukan mau kemana kita mencari barang dagangan, kalau pasaran apa kita harus kemana dan sterusnya, karena nga ada salahnya kita memperayai adat yang sudah diwariskan oleh leluhur dahulu yang penting tetap berdoa dan berusaha].

Dari pemaparan ke tiga narasumber tersebut dapat dijelaskan, bahwa para penebas (pemborong) padi ketika akan berangkat untuk mencari dagangan mereka akan memperhtungkan arah atau lokasi mana yang tepat dalam menjalankan usahanya atau mencari daganganya. Hal ini berbeda dengan penelitian yang dilakukan oleh (Nur Fu'ad, 2015) yang menyatakan bahwa hal yang harus dipertimbangkan dalam memilih lokasi usaha adalah biaya lokasi, kondisi lingkungan dan kedekatan insfratruktur. Hal berbeda juga diungkapan oleh narasumber lainnya yang disajikan sebagai berikut: 
"lek ngolek dagangan ki yo ngendi sing enek, ngak usah ngae perhitungan ngono kuwi.. marai yo kadang ki ngak mesti engko kadong itungane ngalor tibak e kono sisik mari tandur dadi ngak enek pari. Po rayo malah rugi, rugi bensin, wektu, awak kesel ngak oleh dagangan" [kalau mencari barang dagangan mana yang ada dulu, tidak usah memakai perhitungan seperti itu. Karena tidak pasti, kalau perhitungannya ke utara ternyata disana masih musim tanam, jadi tidak ada padinya. Bukanya malah rugi, rugi bahan bakar, waktu, tubuh capek tidak dapat apa-apa]

Berdasarkan pemaparan tersebut bahwa ketika menentukan lokasi usaha harus melihat letak produk apakah tersedia atau tidak. Kalau tidak tersedia di lokasi tersebut dapat menimbulkan kerugian. Kerugian tersebut berupa kerugian biaya transportasi, kerugian waktu dan tenaga.

Petunjuk arah dalam mencari rezeki menurut perhitungan dalam hari 7 dan pasaran 5 dalam Primbon Jawa :

\section{Tabel 1}

Petunjuk arah mata angin dalam menentukan lokasi usaha

\begin{tabular}{llll}
\hline Barat & Utara & Timur & Selatan \\
\hline Jum at legi & Sabtu pahing & Selasa legi & Selasa kliwon \\
Rabu legi & Ahad pon & Jumat pahing & Kamis wage \\
Minggu kliwon & Senin wage & Jum at kliwon & Rabu kliwon \\
Selasa pahing & Sabtu wage & Senin legi & Rabu pahing \\
Minggu pahing & Rabu pon & Jum at pon & Rabu wage \\
Kamis legi & Sabtu legi & Kamis pahing & \\
Kamis pon & Senin pon & & \\
Jum at wage & Selasa wage & & \\
Sabtu kliwon & Sabtu pon & & \\
Minggu legi & Ahad wage & & \\
Kamis kliwon & Senin pahing & & \\
& Selasa pon & & \\
\hline
\end{tabular}

(Sumber: hasil wawancara dengan para narasumber dan buku catatan narasumber)

Berdasarkan tabel tersebut diatas, dapat dilihat bahwa tidak setiap arah dari mata angina merupakan arah yang tepat dalam menentukan lokasi usaha. Hanya arah-arah tertentu yang dianggap dapat membawa rezeji atau membawa keuntungan ketika berusaha. Selain arah dihari dan pasaran yang di sebut di atas maka arah mata angina, hari atau pasaran lainnya di anggap dapat membawa bencana atau kerugian, misalnya naas dan sakit. hal ini sesuai dengan yang di ungkapkan salah satu narasumber sebagai berikut 
"lek golek lokasi usaha laine arah ing dino iku, iso-iso kenek sial, utowo kadung muter-muter blas ndak oleh dagangan utowo rejeki liane"

Hal senada juga diungkapkan narasumber lainnya, berikut kutipan wawancaramya:

“golek dagangan, rejeki, sandang utowo papan ki yo kudu ndelok tuntunane wong jowo. Lek ndak manut malah iso rugu, ndak oleh rejei

Dari yang disampaikan ke dua narasumber tersebut dapat diketahui bahwa kea rah-arah tertentu, hari dan pasaran tertentu saja yang dapat mendatangkan keuntungan. Selain arah, hari dan pasaran tertentu apabila seseorang akan pergi mencari rejeki atau dagangan maka dapat menimbulkan suatu kerugian. Berikut merupakan ringkasan hasil wawancara ara, hari dan pasaran tertentu yang bisa mendatangkan kerugian, yang disajikan dalam tabel 2:

Tabel 2

Arah, hari dan pasaran yang kurang baik

\begin{tabular}{|c|c|c|c|c|}
\hline Ket & Utara & Timur & Selatan & Barat \\
\hline Sandang & $\begin{array}{l}\text { Senin pon, selasa } \\
\text { legi, semua rabu, }\end{array}$ & $\begin{array}{l}\text { Semua minggu, } \\
\text { selasa pon, } \\
\text { semua kamis, } \\
\text { jum at wage }\end{array}$ & $\begin{array}{l}\text { Senin wage, } \\
\text { senin lagi dan } \\
\text { senin pahing, } \\
\text { selasa wage, }\end{array}$ & Semua jum at, \\
\hline Pangan & $\begin{array}{l}\text { Senin wage, senin } \\
\text { legi, senin } \\
\text { pahing, selasa } \\
\text { pon, wage dan } \\
\text { pahing, sabtu } \\
\text { pahing }\end{array}$ & $\begin{array}{l}\text { Senin kliwon, } \\
\text { selasa kliwon, } \\
\text { rabu kliwon, } \\
\text { sabtu pon, }\end{array}$ & $\begin{array}{l}\text { Senin pon, } \\
\text { selasa legi, } \\
\text { rabu } \\
\text { wage,rabu legi, } \\
\text { kamis kliwon, } \\
\text { jum at wage, } \\
\text { jum at } \\
\text { kliwon,sabtu } \\
\text { wage, }\end{array}$ & $\begin{array}{l}\text { Selasa } \\
\text { pon,rabu pon, } \\
\text { rabu pahing, } \\
\text { kamis pon, } \\
\text { kamis wage, } \\
\text { kamis legi } \\
\text { kamis pahin, } \\
\text { sabtu kliwon, } \\
\text { legi }\end{array}$ \\
\hline Naas & $\begin{array}{l}\text { Senin kliwon, } \\
\text { senin pahing, } \\
\text { selasa pon, selasa } \\
\text { legi, semua } \\
\text { kamis, jum at } \\
\text { pon, jum at legi, } \\
\text { sabtu pon, sabtu } \\
\text { kliwon, }\end{array}$ & $\begin{array}{l}\text { Selas pahing, } \\
\text { rabu legi, jumat } \\
\text { wage, sabtu legi }\end{array}$ & $\begin{array}{l}\text { Rabu kliwon, } \\
\text { rabu pahing, } \\
\text { jum at liwon } \\
\text { jum at pahing, }\end{array}$ & $\begin{array}{l}\text { Senin pon, } \\
\text { wage, legi, } \\
\text { selasa } \\
\text { wage,rabu } \\
\text { wage,sabtu } \\
\text { wage, sabtu } \\
\text { pahing }\end{array}$ \\
\hline Sakit & $\begin{array}{l}\text { Selasa pon,jum at } \\
\text { wage }\end{array}$ & $\begin{array}{l}\text { Senin pon, senin } \\
\text { wage, senin legi, } \\
\text { senin pahing, } \\
\text { selasa wage, }\end{array}$ & $\begin{array}{l}\text { Senin kliwon, } \\
\text { rabu pon, } \\
\text { kamis pon, } \\
\text { kamis wage, }\end{array}$ & $\begin{array}{l}\text { Seasa kliwon, } \\
\text { selasa pahing, } \\
\text { rabu kliwon, } \\
\text { rabu legi, }\end{array}$ \\
\hline
\end{tabular}




\begin{tabular}{lll} 
selasa legi, rabu & kamis legi, & kamis kliwon, \\
wage, rabu & kamis pahing, & sabtu pon \\
pahing, sabtu & jum at pon jum & \\
$\begin{array}{l}\text { wage, sabtu } \\
\text { kliwon, sabtu }\end{array}$ & at legi, jum at & \\
pahing & & \\
\hline
\end{tabular}

Sumber: hasil wawancara serta catatan para penebas

Dari tabel 2 diatas dapat dilihat bahwa arah-arah tertentu dan hari serta pasaran tertentu yang dipercaya apabila digunakan untuk mencari rejeki atau berdagang dapat membawa naas atau sakit. Yang dapat diartikan apabila naas atau sakit itu merupakan sebuah kesialan sehingga tidak mendapatkan rejeki atau dagangan.

Menentukan arah mata angin dan hari baik (pasaran) juga bisa digunakan untuk menguatkan psikologis pengusaha dimana adat istiadat bagi masyarakat jawa masih dianut sebagai bentuk penghormatan kepada budaya dan ajaran-ajaran yang disampaikan oleh leluhur dimasa lampau. Selain itu pengusaha (pemborong) sebaiknya memperhatikan ada tidaknya atau ketersedianya produk sehingga dapat meminimalisir kerugian saat mencari dan bertransaksi produk yang akan digunakan.

\section{KESIMPULAN}

Strategi dalam menentukan usaha sangat dibutuhkan bagi pengusaha untuk memenuhi kebutuhan konsumen, adat dan budaya atau kebiasaan-kebiasaan yang berkembang dimasyarakat masih sering digunakan. Hari pasaran dan arah mata angin masih digunakan masyarakat untuk dalam melaksanakan kegiatannya baik dibidang usaha maupun kegiatan lainnya. Menentukan arah mata angin sebagai strategi merupakan salah satu kebiasaan pengusaha dalam menentukan arah dan lokasi dalam menentukan usahanya, dimana kepercaan itu dapat meningkatkan hasil yang diperoleh nantinya. Selain menentukan arah mata angin pengusaha juga memperhatikan ada tidaknya ketersediannya produk yang nantinya digunakan dalam usahanya sehingga dapat meminimalisir kerugian saat mencari dan bertransaksi produk yang akan digunakan dengan memperhitungkan efektivitas waktu, tenaga, dan biaya transportasi.

\section{DAFTAR PUSTAKA}


Eka P, N., Widya Sihwi, S., \& Anggrainingsih, R. (2016). Sistem Penunjang Keputusan Untuk Menentukan Lokasi Usaha Dengan Metode Simple Additive Weighting (SAW). Jurnal Teknologi \& Informasi ITSmart, 3(1), 41. https:/ / doi.org/10.20961/its.v3i1.648

Fitriyani, S., Murni, T., \& Warsono, S. (2019). Pemilihan Lokasi Usaha Dan Pengaruhnya Terhadap Keberhasilan Usaha Jasa Berskala Mikro Dan Kecil. Managament Insight: Jurnal Ilmiah Manajemen, 13(1), 47-58.

https:/ / doi.org/10.33369/insight.13.1.47-58

Maryaeni. (2005). Metode Penelitian Kebudayaan. Bumi Aksara.

Maulana, Y. S. (2018). Analisis Faktor-Faktor yang Mempengaruhi Pemilihan Lokasi Pabrik PT Sung Chang Indonesia Kota Banjar. 2(2), 211-221. https:/ / doi.org/10.31227/osf.io/sxw9h

Moleong, L. J. (2018). Metodologi Penelitian Kualitatif, cet. In XI. Bandung: PT Remaja Rosdakarya.

Musrifah, Arief, M., \& Andriani, N. (2017). Penentuan Lokasi Usaha Berdasarkan Pendekatan Mystique ( Study Fenomenologi ). Jurnal Studi Manajemen Dan Bisnis, 4(2), 288-294.

Nur Fu'ad, E. (2015). Pengaruh Pemilihan Lokasi Terhadap Kesuksesan Usaha Berskala Mikro/Kecil Di Komplek Shopping Centre Jepara. Media Ekonomi Dan Manajemen, 30(1), 56-67.

solihin, I. (2014). Pengantar Bisnis. Erlangga.

Sugiyono, P. D. (2016). metode penelitian kuantitatif, kualitatif,dan R\&D. In Alfabeta, cv. 